\title{
EFFECT OF ROBOT-ASSISTED GAIT TRAINING ON BIOMECHANICS OF ANKLE JOINT IN PATIENTS WITH POST-STROKE HEMIPARESIS
}

Klochkov AS $\bowtie$, Zimin AA, Khizhnikova AE, Suponeva NA, Piradov MA

Research Center of Neurology, Moscow, Russia

The key factor promoting post-stroke gait disturbances is motor impairment of the ankle joint (AJ) which results in pathological synergies. Robotic devices used for gait training are equipped with hip and knee joint actuators. However, there is no consensus in the literature on their effect on AJ movements. The aim of this study was to investigate the effect of robot-assisted gait training on AJ movements in patients with post-stroke paresis. The study recruited 22 hemispheric stroke survivors. They motor function was assessed using clinical scales and motion capture analysis. All patients received 11 robot-assisted gait training session. After rehabilitation, the total score on the Fugl-Meyer Assessment scale increased from 146.5 to 152 points $(p<0.05)$; for the lower limb, the score increased from 18 to 20.5 points $(p<0.05)$. The muscle tone of ankle extensors decreased from 2.5 to 2.0 points on the modified Ashworth scale $(p<0.05)$. The duration of the stance phase increased from 28.0 to $33.5 \%$ relative to the total gait cycle (GC). The main difference in the GC structure before and after rehabilitation is the presence of 3 GC parts instead of 5, suggesting consolidation of patients' goniograms at 1-61\% of GC. Comparison of joint angles before and after rehabilitation revealed that only the interquartile ranges $(\mathrm{IR})$ were different $(p<0.05)$. The authors conclude that robot-assisted training with knee and hip joint actuators indirectly affects the kinematic parameters of AJ by promoting a shift towards the average gait kinematics.

Keywords: stroke, neurorehabilitation, adaptation, gait disturbances, robot-assisted therapy, movement biomechanics, motion analysis Funding: this study was state-funded.

Author contribution: Klochkov AS — study planning, patient recruitment, literature analysis, data interpretation, manuscript preparation; Zimin AA — statistical analysis, data interpretation, manuscript preparation; Khizhnikova AE - literature analysis, data interpretation, manuscript preparation; Suponeva NA, Piradov MA — manuscript preparation.

Compliance with ethical standards: the study was approved by the Ethics Committee of the Research Center of Neurology (Protocol № 14/09 dated December 23, 2009). Informed consent was obtained from all study participants.

$\triangle$ Correspondence should be addressed: Anton S. Klochkov

Volokolamskoe shosse, 80, Moscow, 125367; klochkov@neurology.ru

Received: 28.09.2020 Accepted: 14.10.2020 Published online: 29.10.2020

DOI: $10.24075 / \mathrm{brsmu} .2020 .066$

\section{ВЛИЯНИЕ РОБОТИЗИРОВАННЫХ ТРЕНИРОВОК НА БИОМЕХАНИКУ ГОЛЕНОСТОПНОГО СУСТАВА У ПАЦИЕНТОВ С ПОСТИНСУЛЬТНЫМ ПАРЕЗОМ}

А. С. Клочков $₫$, А. А. Зимин, А. Е. Хижникова, Н. А. Супонева, М. А. Пирадов

Научный центр неврологии, Москва, Россия

Ключевым фактором нарушений походки после острых нарушений мозгового кровообращения (ОНМК) является нарушение движений в голеностопном суставе (ГС), приводящее к формированию патологической синергии. В настоящее время при роботизированных тренировках ходьбы используют приводы тазобедренного и коленного суставов. Однако по данным литературы нет единого мнения об их влиянии на движения в ГС. Целью исследования было изучить влияние роботизированных тренировок ходьбы на движения ГС у пациентов с постинсультным парезом. В исследовании приняло участие 22 пациента с ОНМК полушарной локализации. Для оценки двигательной функции применяли клинические шкалы и видеоанализ ходьбы. Всем пациентам проводили курс из 11 роботизированных тренировок ходьбы. На фоне тренировок выявлено увеличение общего балла по шкале Фугл-Майера со 146,5 до 152 баллов ( < 0,05) и отдельно для нижней конечности с 18 до 20,5 баллов ( $<$ < 0,05), а также снижение мышечного тонуса разгибателей ГС с 2,5 до 2,0 баллов по модифицированной шкале Эшворта ( $<$ 0,05). На фоне роботизированных тренировок отмечено увеличение длительности фазы опоры пациентов с 28,0 до 33,5\% от цикла шага (ЦШ). Кроме того, основным различием структуры ЦШ до и после курса тренировок стало наличие трех частей шага вместо пяти, что подтверждает консолидацию гониограмм пациентов в периоде от 1 до $61 \%$ ЦШ. Сравнение значений углов до и после показало достоверные различия только по межквартильному интервалу ( $p<0,05)$. Авторы пришли к выводу, что роботизированные тренировки с применением активных приводов для тазобедренного и коленного суставов опосредованно способствуют изменениям кинематических параметров ГС за счет приближения показателей паттерна к некоему усредненному шаблону движений.

Ключевые слова: инсульт, нейрореабилитация, нарушения ходьбы, роботизированная терапия, биомеханика движений, видеоанализ движений Финансирование: в рамках государственной НИР

Вклад авторов: А. С. Клочков - планирование исследования, набор пациентов, проведение исследования, анализ литературы, интерпретация данных, подготовка рукописи; А. А. Зимин - статистическая обработка, интерпретация данных, подготовка рукописи; А. Е. Хижникова - анализ литературы, интерпретация данных, подготовка рукописи; Н. А. Супонева, М. А. Пирадов - подготовка рукописи.

Соблюдение этических стандартов: исследование одобрено этическим комитетом Научного центра неврологии (протокол № $14 / 09$ от 23 декабря 2009 г.). Все пациенты подписали добровольное информированное согласие.

$\checkmark$ Для корреспонденции: Антон Сергеевич Клочков

Волоколамское шоссе, д. 80, г. Москва, 125367; klochkov@neurology.ru

Статья получена: 28.09.2020 Статья принята к печати: 14.10.2020 Опубликована онлайн: 29.10.2020

DOI: $10.24075 /$ vrgmu.2020.066

Gait disturbances are among the most debilitating sequelae of stroke [1, 2]. According to a study, over $30 \%$ of stroke survivors were totally unable or required assistance to walk after completing a standard rehabilitation program which did not include robot-assisted gait training [3]. Recent research has shown that exercising with electromechanical gait trainers significantly increases the chance of regaining independent walking [4]. Many authors hold the opinion that 
the altered biomechanics of the ankle joint are the key factor in gait disturbances, causing the pelvis, the trunk and the hip joint to move in an abnormal, energy-inefficient pattern, which negatively affects the quality and speed of walking and results in compensatory synergies [5-8]. Gait rehabilitation is a stepwise process; compensatory strategies used by the patient at the early stages of rehabilitation are perpetuated over time, becoming pathological due to weakness and spasticity in some muscle groups [9].

Currently, robot-assisted gait training is recognized as the gold standard of locomotor poststroke rehabilitation. Metaanalyses confirm the efficacy of electromechanical devices in restoring the impaired walking function, especially in patients who are unable to ambulate independently [4, 10]. Today, two major types of robotic devices are used in neurorehabilitation: exoskeletons and end-effectors, in which a patient's feet are fixed to footplates that simulate walking. Exoskeletons can be divided into 2 categories: mobile and stationary. The list of mobile exoskeletons includes but is not limited to ExoAtlet, $\mathrm{HAL}$ and Bionic leg, which have proved to be effective in clinical rehabilitation [11, 12]. Our literature analysis did not include publications on mobile exoskeletons because the gait pattern simulated by this technology differs from physiological gait; mobile exoskeletons exploit the zero-moment point concept i.e. a locomotion model in which the net force is directed towards the surface to ensure safe locomotion; consequently, the ankle joint torque is limited [13-16 ]. Despite the growing variety of mobile exoskeletons, stationary exoskeletons like Lokomat and ReoAmbulator are more common in clinical practice. So far, both exoskeletons and end-effectors have proved to be clinically effective in helping stroke patients regain their walking function; there is no convincing evidence that one is more beneficial for such patients than the other $[17,18]$. Research shows that end-effector-based training increases ankle joint power and kinetics, expands the range of motion of the knee joint, and improves mobility, walking speed and gait symmetry $[19,20]$. In turn, stationary exoskeletons ensure precise control over the biomechanics of the assisted movement, reproducing the natural motor pattern and thus allowing the patient to correct the pathological gait pattern [21].

There is ongoing debate about the mechanism underlying the effect of robotic devices for the active training of the hip and knee joints on the changes in the biomechanics of the ankle joint, which is not normally actively involved in the training process. Early works looking into the effect of feedbackenhanced robot-assisted training with an exoskeleton on the biomechanics of voluntary movements during walking demonstrated that the natural kinematic patterns of the hip and knee joints were almost identical to the kinematics prescribed by the robot, whereas torque patterns in the joint remained abnormal, indirectly suggesting that the gait pattern prescribed by the robot could not replace the pattern developed by the patient [22].

The need to involve all joints, including the ankle joint, into training and the hypotheses about the beneficial effects of robotic therapy on the proximal/distal leg joints are a common subject of debate. At present, there are a few commercial robotic exoskeletons with ankle joint drives available on the market. However, they are less popular than exoskeletons with hip and knee joints actuators and have some drawbacks. On the whole, there is no unanimous opinion on whether to equip a gait trainer with an ankle joint actuator and on whether it is enough to stimulate only the proximal paretic leg in order to "overwrite" the pathological gait pattern.

At the same time, it is known that locomotor movements are highly automatized and synergistic. So, it would be logical to hypothesize that gait training that provides active robotic assistance and performance feedback for only some movements generated by muscle synergy also produces an indirect effect on the components that do not participate in performing the trained movement.

The aim of our study was to investigate the possibility of improving ankle joint movements by means of gait training with prescribed knee and hip joints patterns in patients with poststroke paresis.

\section{METHODS}

The study conducted in 2010-2017 recruited 22 hemispheric stroke survivors (18 men and 4 women). The median age was 50.5 years $(41 ; 56.5)$, the median time elapsed after stroke was 6.0 months $(2.8 ; 12.9)$. Details are provided in Table 1.

The following inclusion criteria were applied: first-time hemispheric stroke, hemiparesis; gait disturbances.

Exclusion criteria (contraindications to training with the Lokomat) were as follows: weight under $50 \mathrm{~kg}$ or over $135 \mathrm{~kg}$; height below $160 \mathrm{~cm}$ or above $185 \mathrm{~cm}$; lower limb contractures; persistent skin lesions of lower limbs and the trunk; orthostatic hypotension; severe cardiac pathology; severe cognitive impairment; mechanical ventilation; comorbidities and disorders of the locomotory system, including leg length discrepancy $>3 \mathrm{~cm}$; deep vein thrombosis of lower limbs; hip, knee or ankle arthrodesis; osteoporosis; ununited fractures of lower limbs; prescribed bedrest.

The patients were offered a series of robot-assisted gait training sessions with partial body weight support on the Lokomat (Hocoma; Switzerland) equipped with electromechanical drives in the hip and knee joints for flexion and extension and elastic foot lifters for toe clearance support. A total of 11 sessions were conducted; exoskeleton setup and adjustment took 15 min of the first session; the rest of the session (30 min) was spent on reducedintensity gait training to allow each patient to adapt to the prescribed gait pattern. The remaining 10 sessions were 45 min long and consisted of only active gait training with sensory feedback. All sessions were one-on-one personal Lokomat trainings sessions conducted by a therapist, with comfortable walking speed and biofeedback based on the hip and knee potentiometers data. Body weight support was adjusted during each session at the minimal amount of support in order to prevent patients from stumbling. Foot support was ensured by tension springs attached distally to the metatarsal. The degree of spring tension was set up by the therapist during each session to assist the patient's voluntary effort during dorsiflexion and to ensure safe foot clearance.

Table 1. Patients characteristics

\begin{tabular}{|l|c|c|c|c|c|c|c|}
\hline \multicolumn{2}{|c|}{ Sex } & \multicolumn{2}{c|}{ Stroke type } & \multicolumn{2}{c|}{ Hemisphere } & \multicolumn{2}{c|}{ Lesion site } \\
\hline Male & $18(82 \%)$ & Ischemic & $16(72.7 \%)$ & Right & $13(59.1 \%)$ & Corticosubcortical & $8(36.4 \%)$ \\
\hline Female & $4(18 \%)$ & Hemorrhagic & $6(27.3 \%)$ & Left & $9(40.9 \%)$ & Deeper brain structures & $14(63.6 \%)$ \\
\hline
\end{tabular}


For performance feedback, the patients were shown graphs illustrating the level of activity and synchronization of their hip and knee joints with the movements of the exoskeleton. The patients were tasked to perform active movements in the hip and knee joints in synch with the exoskeleton. The graphs reflected active movements of the patient; in the absence of active or synchronized movements, the curve dipped. Apart from robotic therapy, all patients received massages for paretic limbs and ten 30-minute long physical therapy sessions to regain their arm function, balance and walking. Within one hour before and after each Lokomat training session, no other therapeutic procedures were carried out.

The clinical efficacy of robot-assisted rehabilitation was assessed using the validated Russian versions of the FuglMeyer Assessment (FMA) scale, the modified Ashworth (MAS) scale for spasticity in the gastrocnemius and soleus muscles, the modified Rankin (MR) scale, and the Functional Ambulation Categories (FAC) scale [23, 24]. Measurements were performed before the beginning of the rehabilitation program and on the day following its completion.

The biomechanics of walking were evaluated using the motion analysis system (Biosoft-3D; Russia) [25, 26].

For motion capture, we used reflective markers and 2 synchronized infrared digital cameras. The patients were videorecorded for 30 seconds during a 2-minute walking trial on the treadmill at a comfortable speed before and after rehabilitation. The reflective markers were $2 \mathrm{~cm}$ in diameter; they were attached to the anatomic landmarks (projections of joint centers) on the lateral side of the body, including the coracoid process, the most prominent part of the greater trochanter, above the tip of the lateral malleolus, at the heel, and the distal aspect of the foot at the site of the fifth metatarsal head. The kinematic parameters of locomotion were calculated in the $X Y Z$ coordinates $(Z$ - vertical axis; $Y$ - sagittal axis, running from right to left; $X-$ frontal axis). The following kinematic parameters were calculated:

- marker coordinates on the $X, Y, Z$ axes and their movement trajectories;

- angles between body segments and the $X, Y, Z$ axes;

- joint angles.

The second-order low-pass Butterworth filter was applied to the obtained raw data. Kinematic parameters were calculated based on the 3-D coordinates of the reflective markers and the constructed kinetogram of the human body. Temporal characteristics of gait (duration of the stance and swing phases) were used as basic parameters for primary gait analysis; they were calculated based on the local vertical acceleration maximum for the markers attached to the lateral malleolus and the heel plus the local horizontal acceleration maximum for the markers attached to the fifth metatarsal head. Other primary kinematic parameters included maximums and ranges of torque and joint angles in the sagittal plane of the ankle joint. For secondary data analysis, cluster analysis and nonparametric analysis of ten- percentile intervals were used.

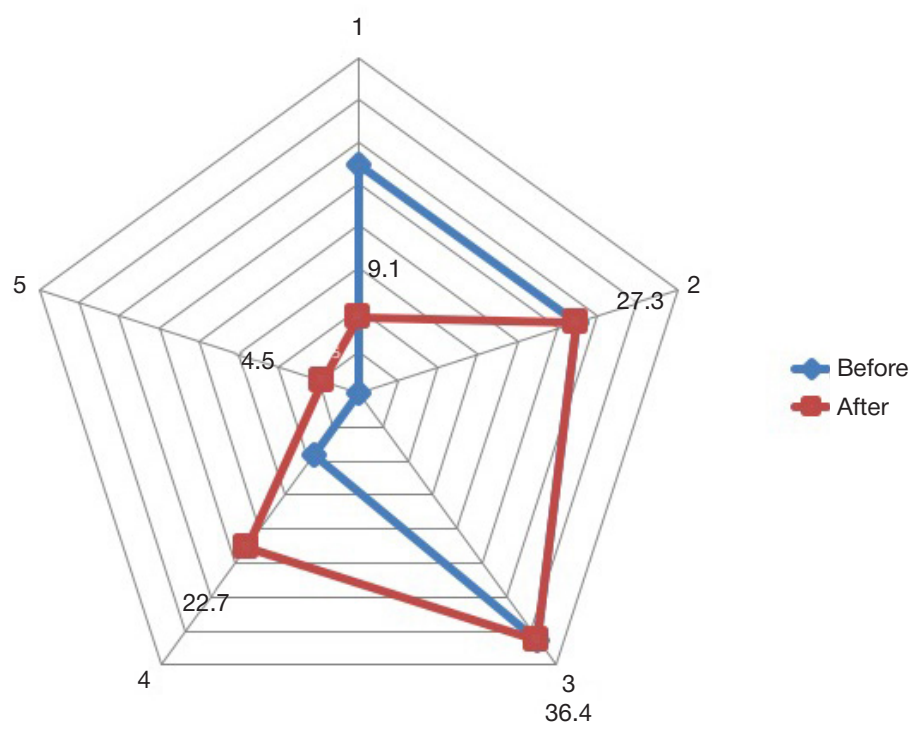

Fig. 1. Distribution of patients on the FAC scale before and after gait rehabilitation

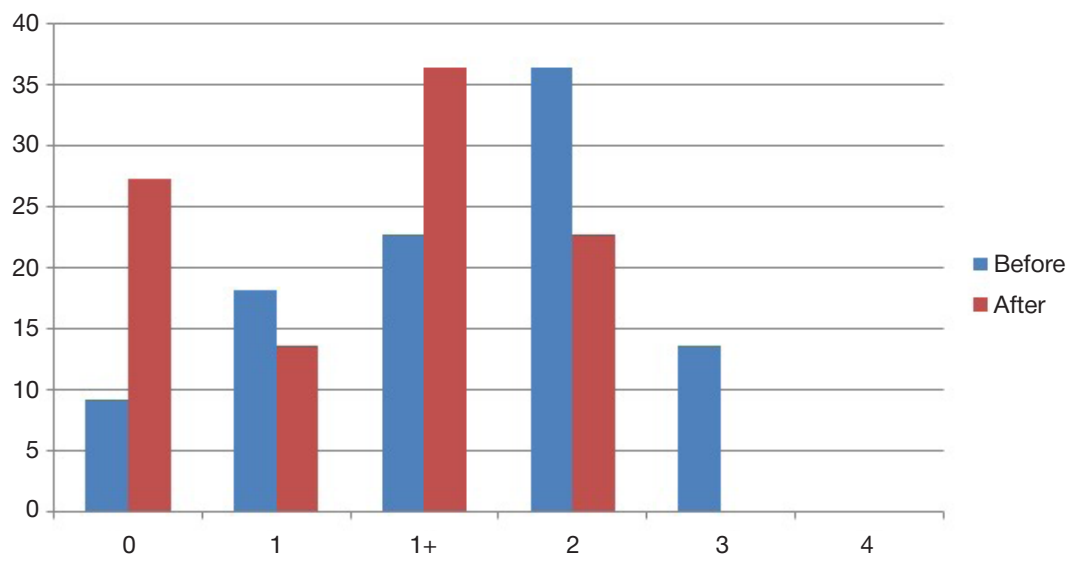

Fig. 2. Distribution of patients on the modified Ashworth scale (represented as percentage) 


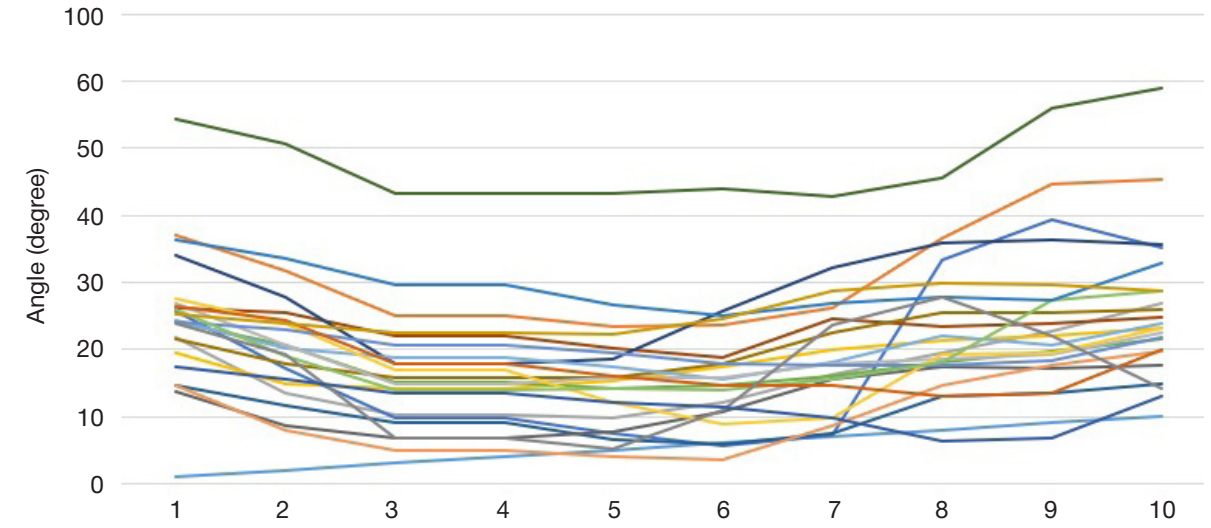

B

Median values for ankle joint angles in the ten-percentile intervals of the gait cycle shown for each patient after rehabilitation

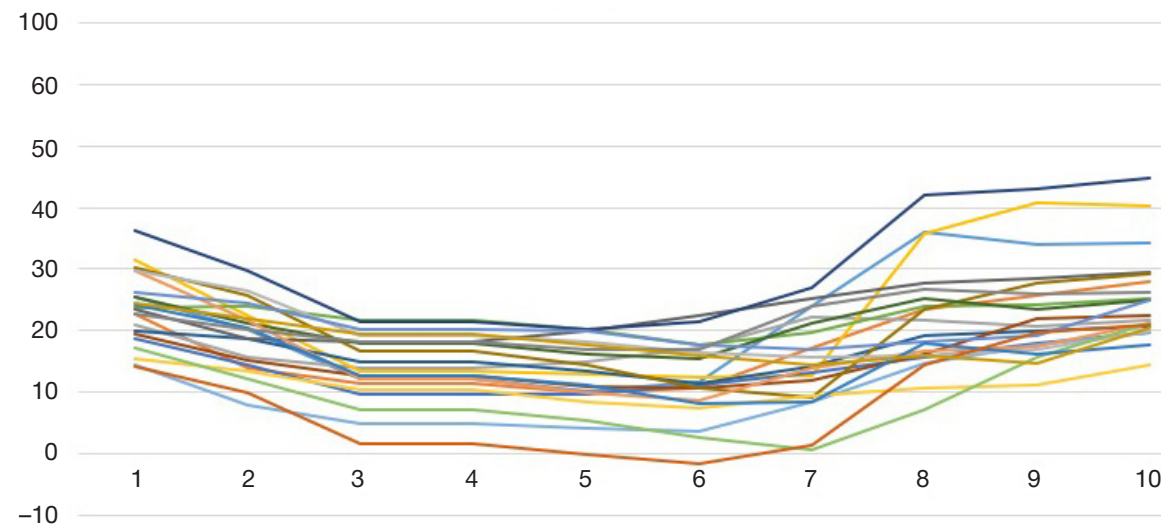

C

Medians of median ankle joint torques in the ten-percentile intervals of the gait cycle before and after rehabilitation

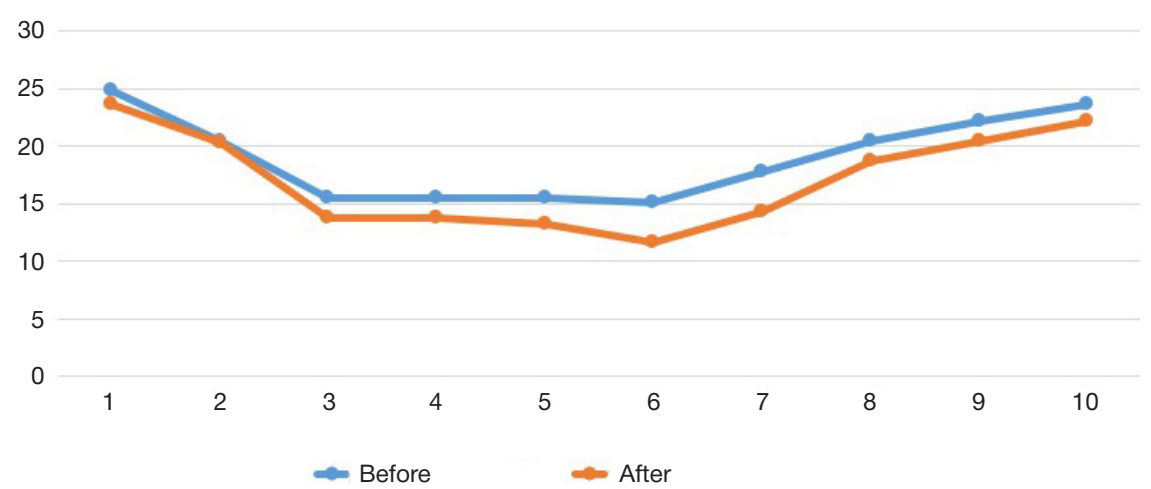

Fig. 3. Goniograms of ankle joint flexion/extension in the ten-percentile intervals of the gait cycle before (A) and after (B) rehabilitation; comparison of median values before and after rehabilitation (C)

Cluster analysis is widely used to study gait in general and the gait cycle in particular in healthy and diseased individuals [2735]. In this work, cluster analysis was applied to identify the structure of the gait cycle and to compare its characteristics before and after rehabilitation. Nonparametric analysis of tenpercentile intervals of the gait cycle was conducted to study the characteristics of the cycle in greater detail and compare them before and after gait rehabilitation.

The obtained data were processed using nonparametric tests: the Mann-Whitney $U$ test for independent variables and the Wilcoxon test for dependent variables. The Bonferroni correction was used to adjust for multiple comparisons. Categorical variables were analyzed using the Fisher exact test. To identify the hierarchy of the obtained data, cluster analysis was applied. Specifically, Ward's method followed by the Mann-Whitney test and the Bonferroni correction procedure was used to identify the components of the gait cycle and subgroups of patients. The strength of associations was evaluated using Spearman's correlation coefficient. Results are presented below as median values, upper and lower quartiles. Differences were considered significant at $p<0.05$. The analysis was carried out in Statistica v. 7.0 (StatSoft Inc; Russia) and SPSS 22 software (IBM; USA).

RESULTS

\section{Clinical efficacy of gait training}

The analysis of clinical data showed that patients' mobility had improved following the rehabilitation program; another finding was an insignificant yet reliable increase in the range of 
Table 2. Comparison of gait cycle parts before and after rehabilitation

\begin{tabular}{|c|c|c|c|c|c|c|c|c|c|}
\hline \multicolumn{2}{|c|}{ Part of gait cycle } & \multicolumn{2}{|c|}{ Median, degrees } & \multicolumn{2}{|c|}{ Q1, degrees } & \multicolumn{2}{|c|}{ Q3, degrees } & \multicolumn{2}{|c|}{ IR, degrees } \\
\hline before & after & before & after & before & after & before & after & before & after \\
\hline $1-7$ & \multirow{3}{*}{$1-61$} & 25.1 & \multirow{3}{*}{16.1} & 22.2 & \multirow{3}{*}{12.7} & 27.4 & \multirow{3}{*}{19.6} & 5.2 & \multirow{3}{*}{$6.9^{\star}$} \\
\hline $8-19$ & & 21.0 & & 16.1 & & 24.6 & & 8.5 & \\
\hline $20-55$ & & 15.6 & & 10.9 & & 19.7 & & 8.8 & \\
\hline 56-74 & 62-75 & 16.9 & 16.6 & 14.2 & 13.1 & 22.5 & 20.8 & 8.3 & 7.7 \\
\hline 75-97 & 76-97 & 22.1 & 20.1 & 18.8 & 18.7 & 27.4 & 24.7 & 8.6 & $6^{\star}$ \\
\hline
\end{tabular}

Note: the data were compared using the Mann-Whitney $U$ and Tukey's tests. ${ }^{*}-p<0.05$

active motion and function of the lower limb and a reduction in gastrocnemius and soleus spasticity in all the participants; the initial degree of disability on the Rankin scale remained unchanged. After gait rehabilitation, a higher proportion of patients could ambulate without assistance than before they joined the program (3, 4 and 5 points on the FAC scale; Fig. 1).

We also observed an increase in active motion on the FM scale after rehabilitation. The total motor score increased from $146.5(128 ; 163.5)$ to $152(134.3 ; 176.8)(p<0.05)$, whereas for the lower extremity, the score increased from $18(16 ; 21)$ to $20.5(18$; 24.3) $(p<0.05)$.

The tone of the gastrocnemius and soleus muscles decreased significantly from $2.5(1 ; 3)$ to $2.0(0 ; 2)$ points on the MAS $(p<0.05)$. Details on the distribution of muscle tone parameters are provided in Fig.2.

\section{Assessment of gait biomechanics}

Temporal and spatial characteristics of gait changed following robot-assisted gait rehabilitation: the duration of the stance phase increased from $28.0 \%(25 ; 36)$ to $33.5 \%(30 ; 42)$ relative to the gait cycle (GC) $(p=0.0001)$.

The analysis of kinematic parameters did not reveal any significant differences in the maximum values for ankle joint flexion and extension during GC. Maximum angle ranges before and after rehabilitation were $59.12^{\circ}$ and $45.30^{\circ}$, respectively, the difference being insignificant $(p=0.228)$. Minimum angle ranges were $3.33^{\circ}$ and $-1.79^{\circ}$, respectively $(p=0.072)$. The differences between the maximum and minimum values were $55.79^{\circ}$ and $47.09^{\circ}$, respectively $(p=0.190)$. However, comparison of the median values of GC ten-percentile intervals before and after rehabilitation revealed that initially different patients' goniograms looked more similar after rehabilitation (Fig. 3A-C).

Considering the absence of significant differences in the primary kinematic parameters, we conducted an in-depth analysis of goniogram variability and ankle joint torques (Table 2).

To determine the degree of data variability, we analyzed the correlation coefficients for the angles between each two consecutive GC parts. Based on the graph (Fig. 4), we concluded that differences between the patients were the most pronounced at $51 \%-58 \%$ and $65 \%-82 \%$ of the gait cycle.

For a more in-depth analysis of ankle joint goniograms constructed before and after rehabilitation, we broke down the gait cycle into parts using cluster analysis and correlation coefficients for each 2 consecutive angles. Using Ward's clustering technique, the gait cycle before rehabilitation was divided into 5 parts corresponding to $1-7 \%, 8-19 \%, 20-55 \%$, $56-74 \%$, and $75-100 \%$ of GC. The first part corresponded to the time of foot contact with the treadmill and the beginning of the stance phase; the second part corresponded to the middle of the stance phase; the third part, to the end of the stance phase and the beginning of the swing phase; the fourth part, to the middle of the swing phase; the fifth part, to the end of the swing phase. Cluster analysis was applied to each GC part. Descriptive statistics for GC parts before clustering are provided in Table 3.

After 5 parts were identified in the pre-rehabilitation gait cycle, the patients were clustered into subgroups for each of those parts. Two clusters were identified in the first part of the cycle (1-7\%). The second part (8-19\%) was represented by 3 clusters, differing in their medians. In the third (20-55\%) and fourth (56-74\%) parts, 3 and 4 clusters were identified, respectively, differing in medians. The fifth part (75-97\%) was

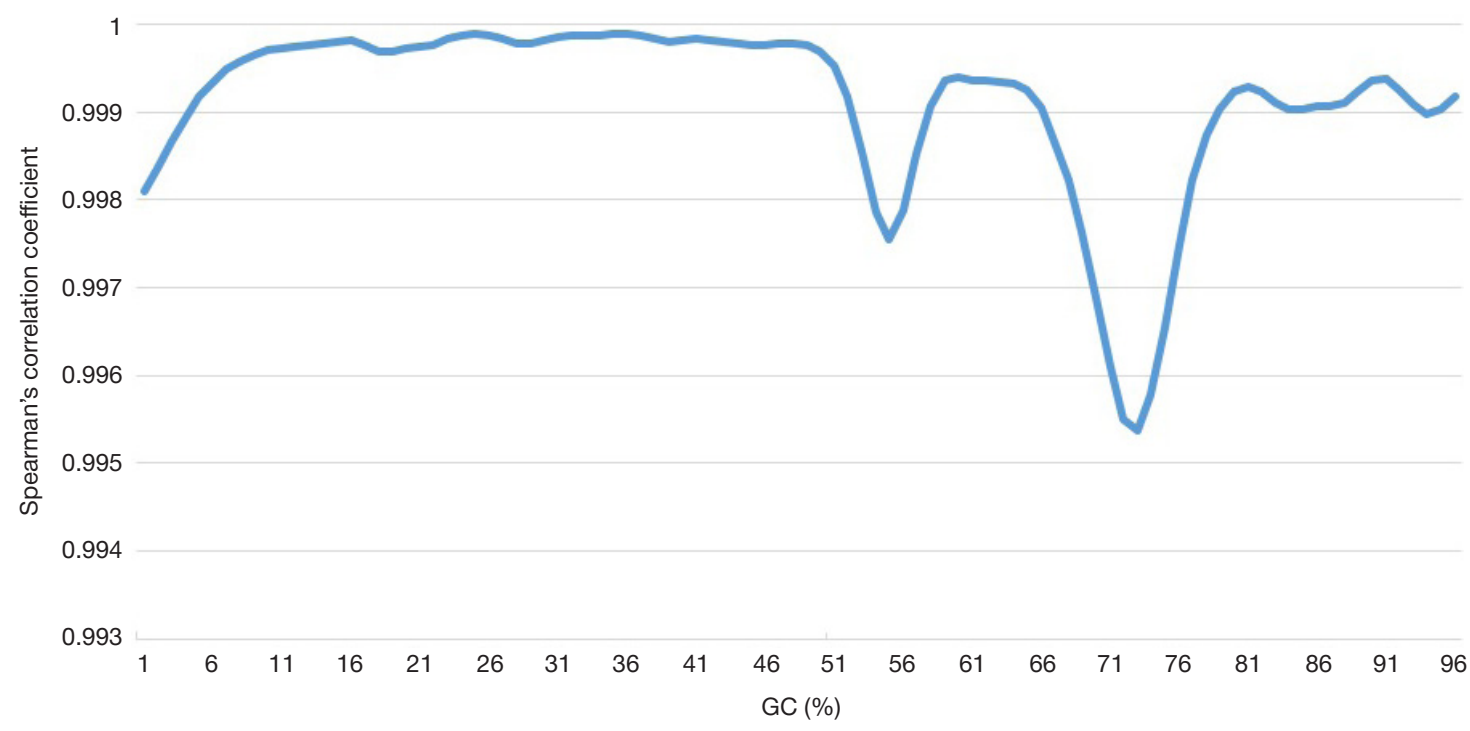

Fig. 4. The ankle joint angle range correlation coefficient for each two consecutive GC parts on the goniograms 
Table 3. Statistical characteristics of GC parts

\begin{tabular}{|l|c|c|c|c|}
\hline \multicolumn{1}{|c|}{ Part of gait cycle } & Median, degrees & Q1, degrees & Q3, degrees & IR, degrees \\
\hline $1-7 \%$ & 25.1 & 22.2 & 27.4 & 5.2 \\
\hline $8-19 \%$ & 21.0 & 16.1 & 24.6 & 8.5 \\
\hline $20-55 \%$ & 15.6 & 10.9 & 19.7 & 8.8 \\
\hline $56-74 \%$ & 16.9 & 14.2 & 22.5 & 8.3 \\
\hline $75-100 \%$ & 22.1 & 18.8 & 27.4 & 8.6 \\
\hline
\end{tabular}

represented by 3 clusters. Based on the post-rehabilitation goniograms, Ward's clustering identified 3 parts in the postrehabilitation gait cycle at $1-61 \%, 62-75 \%$ and $76-97 \%$ of the cycle. There were 3 clusters identified in the first part, 2 clusters in the second, and 3 clusters in the third. Thus, the main difference in the GC structure before and after rehabilitation was the presence of 3 parts instead of 5 , suggesting consolidation of the goniograms at $1-61 \%$ of the gait cycle. Angle comparison before and after rehabilitation demonstrated significant differences in IR only $(p<0.05)$.

The analysis of torque medians in the ten-percentile intervals of the gait cycle before and after rehabilitation also revealed consolidation of these parameters after completion of the rehabilitation program; the most pronounced differences in torques were observed during dorsiflexion in the swing phase (Fig. 5A-C).

Comparison of torque medians in the ten-percentile GC intervals for each patient before and after rehabilitation revealed that torque patterns became more similar after rehabilitation. In almost all our patients, torque peaked during the $7^{\text {th }}$ ten-percentile interval of the gait cycle $(71-80 \%)$, which corresponds to the middle of the swing phase. The second, not so pronounced peak was observed in the $10^{\text {th }}$ ten-percentile interval of the cycle (91-97\%), which corresponds to the end of the swing phase. Statistical analysis showed that the observed changes were associated with Q3 changes and joint torque peaks. During the second half of pre-rehabilitation GC, 3 torque peaks were detected at 55\%, 75\% (the absolute maximum) and $95 \%$ of the cycle. After rehabilitation, there were also 3 torque peaks; however, the first and second peaks almost "fused" into a single peak. After rehabilitation, the first and the second torque peaks were lower than before the program; the third peak was almost the same before and after rehabilitation (Fig. 6).

Summing up, there was an increase in voluntary activity of the lower limb on the FMA scale, a reduction in gastrocnemius and soleus muscles spasticity on the MAS and functional improvement on the FAC scale in patients with post-stroke hemiparesis after robot-assisted gait rehabilitation.

Thorough analysis of movement biomechanics allowed us to identify changes in the GC structure (an increase in the duration of the stance phase) and ankle joint angles/torques (a reduction in the variability and fusion of torque peaks).

\section{DISCUSSION}

GC asymmetry is one of the most common gait disturbances beside reduced walking speed and shorter step length observed in stroke survivors. In GC asymmetry, the stance phase becomes shorter, whereas the swing phase of the paretic limb becomes longer, which is reflected in the temporal characteristics of the gait cycle before rehabilitation [2]. The increase in the duration of the stance phase from $28.0 \%$ (25; $36)$ to $33.5 \%(30 ; 42)$ relative to the entire length of the GC following gait training might be the result of improved strength in the muscles supporting the paretic limb, improved weight shifting, reduced spasticity, and better coordination between the joints. It is known that high muscle tone of ankle flexors prevents the foot from dorsiflexion, forcing the body to stop its forward propulsion; the center of gravity is thus left behind the ankle joint line, the swing phase of the healthy leg becomes shorter, resulting in a shorter step. According to some authors [36], robot-assisted training can reduce spasticity in ankle extensor muscles and indirectly affect the recovery of gait symmetry. This hypothesis is supported by our findings concerning muscle tone reduction in the gastrocnemius and soleus muscles. Reduced muscle tone might promote ankle dorsiflexion during the stance phase. However, no significant differences in the range of motion during the stance phase were detected, which might be explained by the limited amplitude of the ankle dorsiflexion movement in the middle of the stance phase (the range of motion does not exceed $10^{\circ}$ at the moment when the center of mass passes the center of pressure) [37]. At the same time, consolidation of ankle joint goniograms before the time point corresponding to $61 \%$ of the gait cycle (this part includes the stance phase and the beginning of the swing phase) indirectly suggests a positive effect of the prescribed physiological pattern of the center of mass movement on the ankle joint kinematics during the stance phase.

Apart from the stance and swing phases, some researchers identify 6 phases in the physiological gait biomechanics designated by the peak values of its dynamic parameters $[38,39]$. Among these phases, the part at $60-73 \%$ of the GC corresponds to the acceleration phase, which begins when the foot leaves the ground and ends when the swing leg is adjacent to the stance leg. In this phase, the body gains up speed to advance the leg forward. In the next part of the cycle (73-87\%) the foot passively advances further. This phase begins when the swing leg is adjacent to the stance leg and ends when the swing leg is in front of the body and its tibia is vertical [2,40].

We found that in patients with poststroke paresis the biomechanics of the ankle joint were changed after gait rehabilitation: the joint was stable during the stance phase and the dorsiflexion movement was faster and smoother as the leg was advancing forward, ensuring sufficient foot clearance. Such changes might be promoted by the synergy of the hip and knee joints prescribed by the robotic trainer and the lack of opportunity to use compensatory strategies for better foot clearance. Perhaps, robot-assisted gait training has a certain universal tuning effect on the ankle joint movement resulting from the correction of the compensatory synergy of the hip and knee joints, reflected in the reduced data variability $(p<0.05$; Mann-Whitney $U$ ), smaller number of the identified clusters and less differing medians after rehabilitation. However, patient clusters identified before and after rehabilitation were very different. This leads us to hypothesize that since patients move to other clusters as they continue gait training, the effect is achieved through different mechanisms, despite the overall "leveling" effect of rehabilitation on the gait pattern. 
A

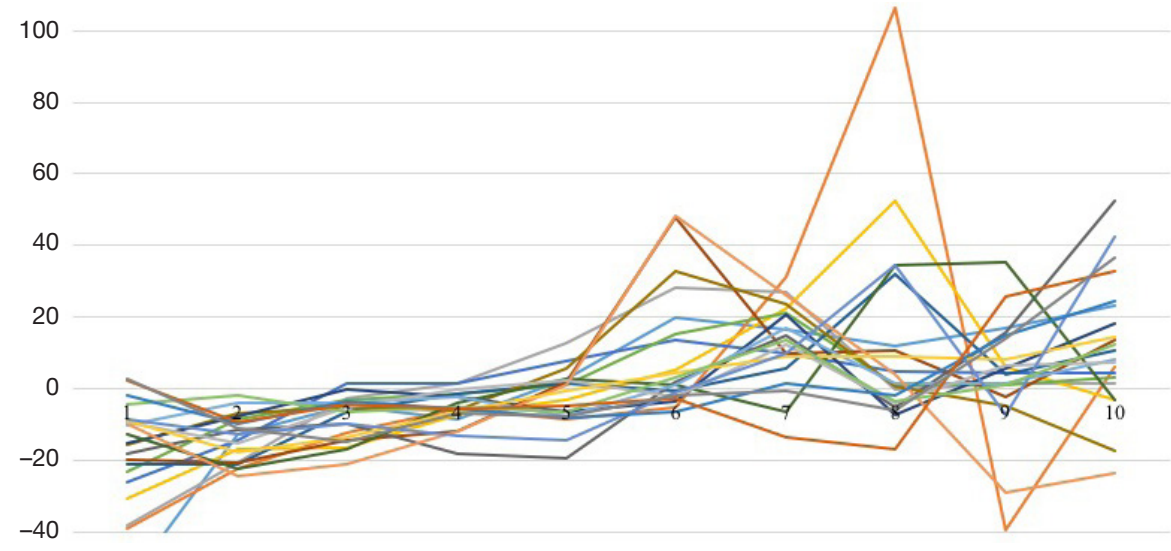

B Median values for ankle joint torques in the ten-percentile intervals of the gait cycle shown for each patient after rehabilitation

100

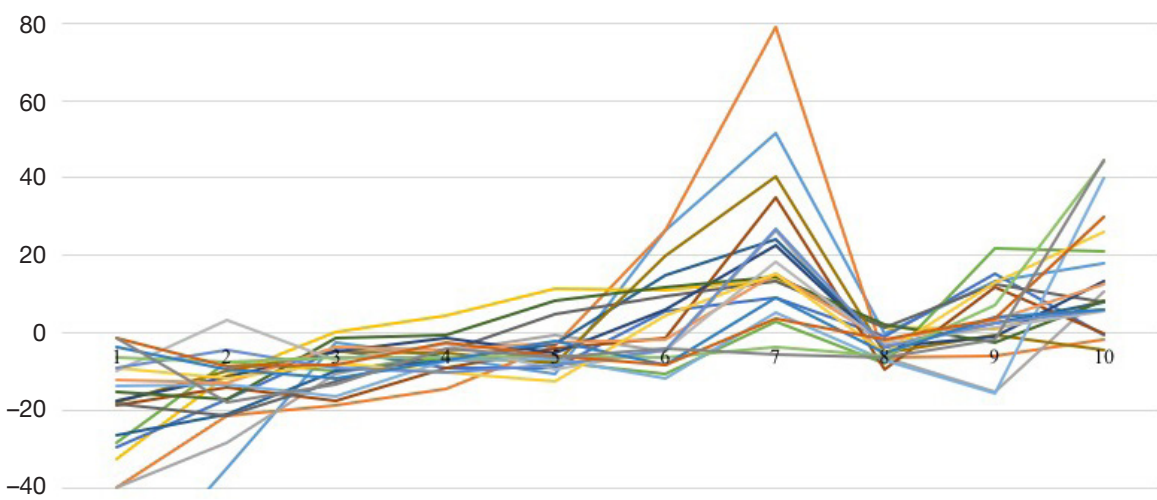

C

Medians of median ankle joint torques in the ten-percentile intervals of the gait cycle before and after rehabilitation

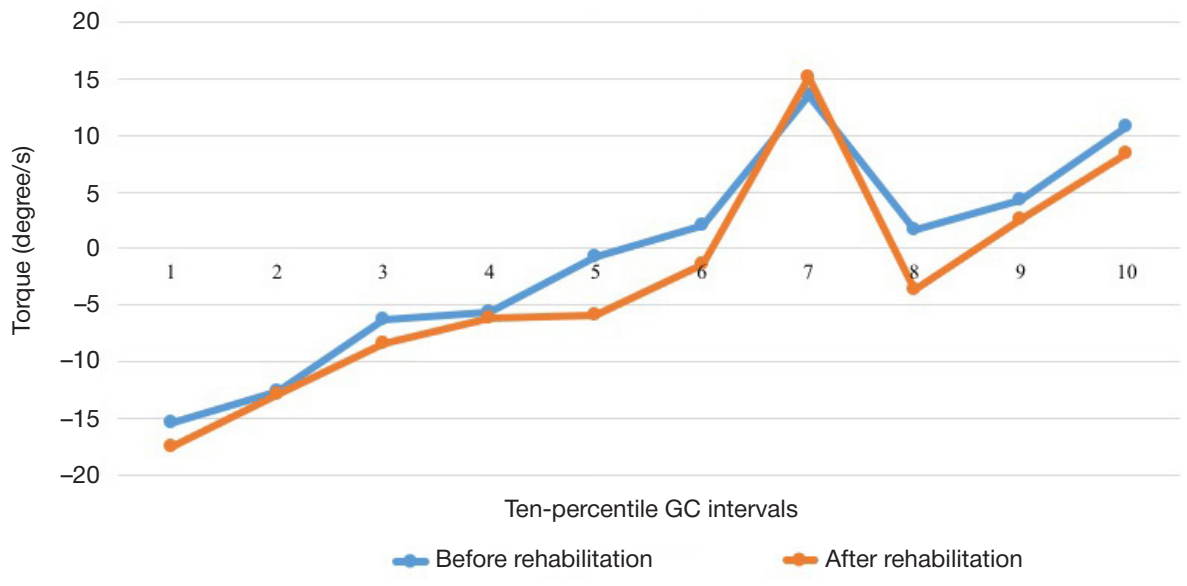

Fig. 5. Characteristics of the ten-percentile intervals of the gait cycle in the ankle joint of the paretic limb before (A) and after (B) rehabilitation; comparison of median values before and after rehabilitation $(\mathbf{C})$

Comparison of the total sum of angles in the gait cycle reveals that peak values leveled out as other patients showed a shift towards the median. Therefore, we conclude that there were no significant changes in the total sum of ankle joint angles after rehabilitation ( $p=0.521$; Mann-Whitney $U$ ). This suggests that structural changes in the gait pattern are not determined by quantitative parameters but are largely the result of the shift in the gait pattern towards the values characteristics of the average gait pattern. Some studies demonstrate that ankle joint angles change following gait rehabilitation, leading to improved dorsiflexion, but those changes were detected in patients with moderate motor deficit in the ankle joint [40].

Hypothetically, therapy can target not the compensatory muscle synergy as a whole, but some of its components. If its components are more or less equally important, it does not matter which one is directly targeted. However, if the compensatory muscle synergy is not completely formed, the best correctional effect can be achieved by targeting the movement that initiated the development of compensatory synergies.

Our study has a few limitations. During motion capture, the patients were walking on the treadmill which was not equipped 


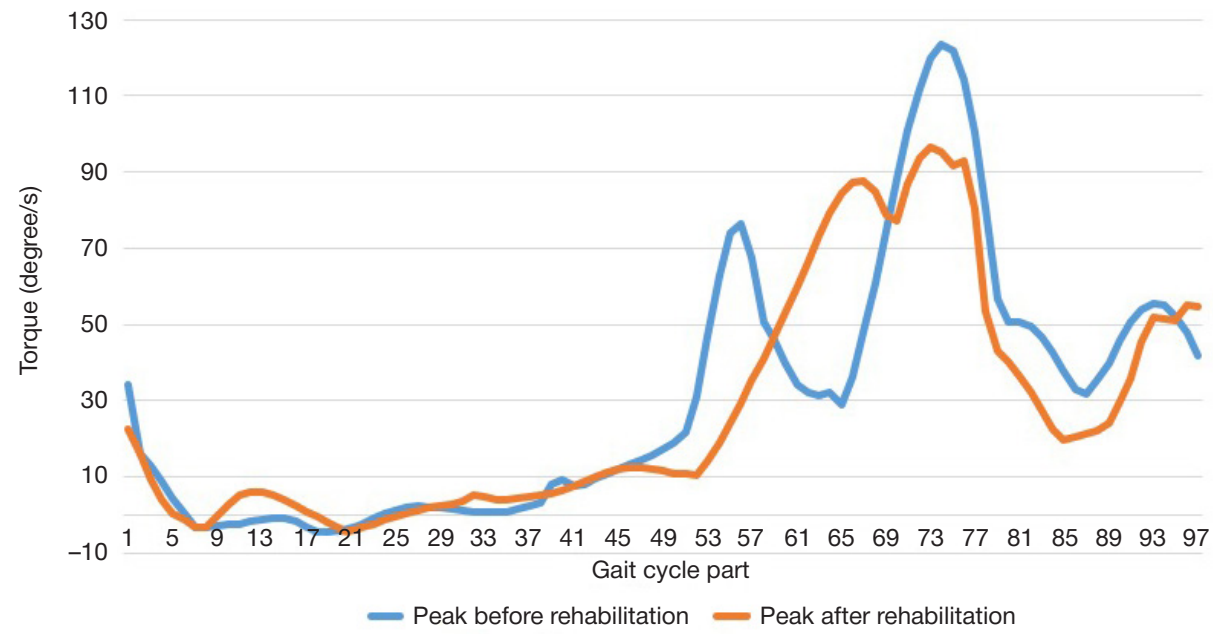

Fig. 6. Torque peaks during ankle flexion/extension of the paretic limb at different gait cycle timepoints before and after rehabilitation

with force plates, so we were unable to analyze support reaction forces. To better understand the biomechanics of the studied joints, further research should be focused on comparing patients and healthy individuals and analyzing the follow-up data and EMG results for muscle activity.

\section{CONCLUSIONS}

Robot-assisted gait training of the hip and knee joints can cause changes in ankle goniograms and ankle joint torques in patients with pathological synergies, improving the biomechanics of the ankle joint. Further research should focus on the comprehensive analysis of the movements of the paretic and healthy leg, pelvis and trunk. Besides, in order to understand the mechanisms promoting changes in muscle synergies, the study protocol should include groups with different exposure to training. The analysis of the effect that robotic therapy has on complex movements will allow to design new training protocols accounting for the presence and severity of pathological compensatory gait patterns.

\section{References}

1. Balaban B, Tok F. Gait Disturbances in Patients With Stroke. J PM\&R. 2014; 6 (7): 635-42.

2. Beyaert C, Vasa R, Frykberg GE. Gait post-stroke: Pathophysiology and rehabilitation strategies. J Neurophysiol Clin. 2015; 45 (4-5): 335-55.

3. Jørgensen HS, Nakayama $\mathrm{H}$, Raaschou $\mathrm{H}$, et al. Recovery of walking function in stroke patients: The copenhagen stroke study. J Arch Phys Med Rehabil. 1995; 76 (1): 27-32.

4. Mehrholz J, Thomas S, Werner C, et al. Electromechanicalassisted training for walking after stroke. Cochrane Database Syst Rev. 2017: 5

5. Skvortsov DV. Klinicheskiy analiz dvizheniy. Analiz pokhodki. Ivanovo: Stimul, 1996; 344 s. Russian.

6. Kim CM, Eng JJ. Magnitude and pattern of $3 \mathrm{D}$ kinematic and kinetic gait profiles in persons with stroke: relationship to walking speed. Gait Posture. 2004; 20 (2): 140-6.

7. Milot M-H, Nadeau S, Gravel D. Muscular utilization of the plantarflexors, hip flexors and extensors in persons with hemiparesis walking at self-selected and maximal speeds. $J$ Electromyogr Kinesiol. 2007; 17 (2): 184-193.

8. Sadeghi $H$, Allard P, Duhaime M. Muscle power compensatory mechanisms in below-knee amputee gait. Am J Phys Med Rehabil. 2001; 80 (1): 25-32.

9. Brunnstrom S. Movement Therapy in Hemiplegia: A Neurophysiological Approach. Harper \& Row. 1970; 192.

10. Bruni MF, Corrado M, De Cola MC, et al. What does best evidence tell us about robotic gait rehabilitation in stroke patients: A systematic review and meta-analysis. J Clin Neurosci. 2018; 48: $11-17$.

11. Tan $\mathrm{CH}$, Kadone $\mathrm{H}$, Watanabe $\mathrm{H}$, Marushima $\mathrm{A}$ et al. Latera Symmetry of Synergies in Lower Limb Muscles of Acute Post-stroke Patients After Robotic Intervention. Frontiers in Neuroscience. 2018; 12: 276.

12. Pismennaya EV, Petrushanskaya KA, Kotov SV, et al. Clinical and biomechanical foundation of application of the exoskeleton

exoatlet at walking of patients with poststroke disturbances. Russian Journal of biomechanics. 2019; 23 (2): 204-30. Russian.

13. Vukobratovíc M, Borovac B. Zero-moment point-thirty five years of its life. International Journal of Humanoid Robotics. 2004; 1 (1): 157-73.

14. Mokhtari M, Taghizadeh M, Mazare M. Hybrid Adaptive Robust Control Based on CPG and ZMP for a Lower Limb Exoskeleton. Robotica. 2020: 1-19.

15. Al-Shuka H, Corves B, Vanderborght B, et al. Zero-Moment PointBased Biped Robot with Different Walking Patterns. International Journal of Intelligent Systems and Applications (IJISA). 2015; 7: $31-41$.

16. Erbatur K, Kurt O. Natural ZMP Trajectories for Biped Robot Reference Generation. IEEE Transactions on Industrial Electronics. 2009; 56 (3): 835-45.

17. Schwartz I, Meiner Z. Robotic-Assisted Gait Training in Neurological Patients: Who May Benefit? Ann Biomed Eng. 2015; 43 (5): 1260-9.

18. Moucheboeuf G, Griffier R, Gasq D. Effects of robotic gait training after stroke: a meta-analysis. Ann Phys Rehabil Med. 2020; S.1877-0657(20)30065-8. DOI: 10.1016/j.rehab.2020.02.008.

19. Aprile I, lacovelli C, Goffredo M, et al. Efficacy of end-effector RobotAssisted Gait Training in subacute stroke patients: Clinical and gait outcomes from a pilot bi-centre study. NeuroRehabilitation. 2019; 45 (2): 201-12.

20. De Luca A, Vernetti H, Capra C, et al. Recovery and compensation after robotic assisted gait training in chronic stroke survivors. Disabil Rehabil Assist Technol. 2019; 14 (8): 826-38.

21. Klochkov AS, Telenkov AA, Chernikova LA. Effect of Lokomat trainings on the severity of gait disorders in patients after stroke. Annals of Clinical and Experimental Neurology. 2011; 5 (3): 20-25.

22. Neckel ND, Blonien N, Nichols D, et al. Abnormal joint torque patterns exhibited by chronic stroke subjects while walking with a prescribed physiological gait pattern. J Neuroeng Rehabil. 2008; 5 (1): 1-13. 
23. Suponeva NA, Yusupova DG, Zhirova ES, at al. Validation of the modified Rankin Scale in Russia. J Neurology, Neuropsychiatry, Psychosomatics. 2018; 10 (4): 36-39.

24. Suponeva NA, Yusupova DG, Ilyina KA, et al. Validation of the Modified Ashworth scale in Russia. J Annals of clinical and experimental neurology. 2020; 14 (1): 89-96.

25. Shpakov AV, Artamonov AA, Orlov DO, i dr. Novye podhody v obrabotke biomehanicheskih harakteristik lokomocij cheloveka, poluchennyh s ispol'zovaniem videoanaliza dvizhenij. Upravlenie dvizheniem Motor Control 2020 materialy VIII Rossijskoj s mezhdunarodnym uchastiem konferencii po upravleniju dvizheniem. 2020; 65-66.

26. Docenko VI, Voronov AV, Titarenko NYu, i dr. Komp'juterny videoanaliz dvizhenij $v$ sportivnoj medicine i nejroreabilitacii. Medicinskij alfavit. 2005; 3: 12-14.

27. Ferrarin M, Bovi G, Rabuffetti M, et al. Gait pattern classification in children with Charcot-Marie-Tooth disease type 1A. Gait and Posture. 2012; 35: 131-7.

28. Kaczmarczyk K, Wit A, Krawczyk M, et al. Gait classification in poststroke patients using artificial neural networks. Gait and Posture. 2009; 30 (2): 207-10

29. Toro B, Nester CJ, Farren PC. Cluster analysis for the extraction of sagittal gait patterns in children with cerebral palsy. Gait and Posture. 2007; 25: 157-65.

30. Giacomozzi C, Martelli F, Nagel A, et al. Cluster analysis to classify gait alterations in rheumatoid arthritis using peak pressure curves. Gait and Posture. 2009; 29: 220-4.

31. Fong-Chin S, Wen-Lan W, Yuh-Min C, et al. Fuzzy clustering of gait patterns of patients after ankle arthrodesis based on

\section{Литература}

1. Balaban B, Tok F. Gait Disturbances in Patients With Stroke. J PM\&R. 2014; 6 (7): 635-42.

2. Beyaert C, Vasa R, Frykberg GE. Gait post-stroke: Pathophysiology and rehabilitation strategies. J Neurophysiol Clin. 2015; 45 (4-5): 335-55.

3. Jørgensen HS, Nakayama $\mathrm{H}$, Raaschou $\mathrm{H}$, et al. Recovery of walking function in stroke patients: The copenhagen stroke study. J Arch Phys Med Rehabil. 1995; 76 (1): 27-32.

4. Mehrholz J, Thomas S, Werner C, et al. Electromechanicalassisted training for walking after stroke. Cochrane Database Syst Rev. 2017: 5 .

5. Скворцов Д. В. Клинический анализ движений. Анализ походки. Иваново: Стимул, 1996; 344 с.

6. Kim CM, Eng JJ. Magnitude and pattern of 3D kinematic and kinetic gait profiles in persons with stroke: relationship to walking speed. Gait Posture. 2004; 20 (2): 140-6.

7. Milot M-H, Nadeau S, Gravel D. Muscular utilization of the plantarflexors, hip flexors and extensors in persons with hemiparesis walking at self-selected and maximal speeds. $J$ Electromyogr Kinesiol. 2007; 17 (2): 184-193.

8. Sadeghi H, Allard P, Duhaime M. Muscle power compensatory mechanisms in below-knee amputee gait. Am J Phys Med Rehabil. 2001; 80 (1): 25-32.

9. Brunnstrom S. Movement Therapy in Hemiplegia: A Neurophysiological Approach. Harper \& Row. 1970; 192.

10. Bruni MF, Corrado M, De Cola MC, et al. What does best evidence tell us about robotic gait rehabilitation in stroke patients: A systematic review and meta-analysis. J Clin Neurosci. 2018; 48: $11-17$.

11. Tan $\mathrm{CH}$, Kadone $\mathrm{H}$, Watanabe $\mathrm{H}$, Marushima $\mathrm{A}$, et al. Lateral Symmetry of Synergies in Lower Limb Muscles of Acute Post-stroke Patients After Robotic Intervention. Frontiers in Neuroscience. 2018; 12: 276.

12. Письменная Е. В., Петрушанская К. А., Котов С. В. и др. Клинико-биомеханическое обоснование применения экзоскелета «Экзоатлет» при ходьбе больных с последствиями ишемического инсульта. Российский журнал биомеханики. 2019; 23 (2): 204-30

13. Vukobratovíc M, Borovac B. Zero-moment point-thirty five years kinematic parameters. Med Eng Phys. 2001; 23: 83-90.

32. Rozumalski A, Schwartz M. Crouch gait patterns defined using k-means cluster analysis are related to underlying clinical pathology. Gait and Posture. 2009; 30: 155-60.

33. Mulroy S, Gronley J, Weiss W, et al. Use of cluster analysis for gait pattern classification of patients in the early and late recovery phases following stroke. Gait and Posture. 2003; 18: 114-25.

34. Phinyomark A, Osis S, Hettinga BA, Ferber R. Kinematic gait patterns in healthy runners: A hierarchical cluster analysis. J Biomech. 2015; 48 (14): 3897-904.

35. Watari R, Osis ST, Phinyomark A, Ferber R. Runners with patellofemoral pain demonstrate sub-groups of pelvic acceleration profiles using hierarchical cluster analysis: an exploratory crosssectional study. BMC Musculoskeletal Disorders. 2018; 19: 120.

36. Trompetto C, Marinelli L, Mori L, et al. Postactivation depression changes after robotic-assisted gait training in hemiplegic stroke patients. Gait Posture. 2013; 38 (4): 729-33.

37. Skvortsov DV. Diagnostika dvigatel'noy patologii instrumental'nymi metodami: analiz pokhodki stabilometriya. M., 2007; 640 s.

38. Vitenson AS, Petrushanskaya KA. Physiological foundations of a method of artificial correction of movements by means of programmable electrical stimulation of muscles during walking. Russian Journal of biomechanics. 2005; 9 (1): 7-26.

39. Vorontcova OI, Lozovskaya MV. Structure of gait cycle based on kinetic and kinematical parameters. Journal of new medical technologies. 2017; 3: 9-15

40. Bonnyaud C, Zory R, Boudarham J, et al. Effect of a robotic restraint gait training versus robotic conventional gait training on gait parameters in stroke patients. Exp Brain Res. 2014; 232 (1): 31-42.

of its life. International Journal of Humanoid Robotics. 2004; 1 (1): $157-73$

14. Mokhtari M, Taghizadeh M, Mazare M. Hybrid Adaptive Robust Control Based on CPG and ZMP for a Lower Limb Exoskeleton. Robotica. 2020: 1-19.

15. Al-Shuka H, Corves B, Vanderborght B, et al. Zero-Moment PointBased Biped Robot with Different Walking Patterns. International Journal of Intelligent Systems and Applications (IJISA). 2015; 7: $31-41$.

16. Erbatur K, Kurt O. Natural ZMP Trajectories for Biped Robot Reference Generation. IEEE Transactions on Industrial Electronics. 2009; 56 (3): 835-45.

17. Schwartz I, Meiner Z. Robotic-Assisted Gait Training in Neurological Patients: Who May Benefit? Ann Biomed Eng. 2015; 43 (5): 1260-9.

18. Moucheboeuf G, Griffier R, Gasq D. Effects of robotic gait training after stroke: a meta-analysis. Ann Phys Rehabil Med. 2020; S.1877-0657(20)30065-8. DOI: 10.1016/j.rehab.2020.02.008.

19. AprileI, lacovelli $C$, Goffredo M, et al. Efficacy of end-effector RobotAssisted Gait Training in subacute stroke patients: Clinical and gait outcomes from a pilot bi-centre study. NeuroRehabilitation. 2019; 45 (2): 201-12.

20. De Luca A, Vernetti H, Capra C, et al. Recovery and compensation after robotic assisted gait training in chronic stroke survivors. Disabil Rehabil Assist Technol. 2019; 14 (8): 826-38.

21. Клочков А. С., Теленков А. А., Черникова Л. А. Влияние тренировок на системе «Lokomat» на выраженность двигательных нарушений у пациентов, перенесших инсульт. Анналы клинической и экспериментальной неврологии. 2011; 5 (3): 20-25.

22. Neckel ND, Blonien N, Nichols D, et al. Abnormal joint torque patterns exhibited by chronic stroke subjects while walking with a prescribed physiological gait pattern. J Neuroeng Rehabil. 2008; 5 (1): 1-13.

23. Супонева Н. А. Юсупова Д. Г. Жирова Е. С. и др. Валидация модифицированной шкалы Рэнкина (The Modified Rankin Scale, MRS) в России. Неврология, нейропсихиатрия, психосоматика. 2018; 10 (4): 36-39.

24. Супонева Н. А., Юсупова Д. Г., Ильина К. А. и др. Валидация 
модифицированной шкалы Эшворта (modified ashworth scale) в России. Анналы клинической и экспериментальной неврологии. 2020; 14 (1): 89-96.

25. Шпаков А. В., Артамонов А. А., Орлов Д. О. и др. Новые подходы в обработке биомеханических характеристик локомоций человека, полученных с использованием видеоанализа движений. Управление движением Motor Control 2020 материалы VIII Российской с международным участием конференции по управлению движением. 2020; 65-66.

26. Доценко В. И., Воронов А. В., Титаренко Н. Ю. и др. Компьютерный видеоанализ движений в спортивной медицине и нейрореабилитации. Медицинский алфавит. 2005; 3: 12-14.

27. Ferrarin M, Bovi G, Rabuffetti M, et al. Gait pattern classification in children with Charcot-Marie-Tooth disease type 1A. Gait and Posture. 2012; 35: 131-7.

28. Kaczmarczyk K, Wit A, Krawczyk M, et al. Gait classification in poststroke patients using artificial neural networks. Gait and Posture. 2009; 30 (2): 207-10.

29. Toro B, Nester CJ, Farren PC. Cluster analysis for the extraction of sagittal gait patterns in children with cerebral palsy. Gait and Posture. 2007; 25: 157-65.

30. Giacomozzi C, Martelli F, Nagel A, et al. Cluster analysis to classify gait alterations in rheumatoid arthritis using peak pressure curves. Gait and Posture. 2009; 29: 220-4.

31. Fong-Chin S, Wen-Lan W, Yuh-Min C, et al. Fuzzy clustering of gait patterns of patients after ankle arthrodesis based on kinematic parameters. Med Eng Phys. 2001; 23: 83-90.

32. Rozumalski A, Schwartz M. Crouch gait patterns defined using k-means cluster analysis are related to underlying clinical pathology. Gait and Posture. 2009; 30: 155-60.

33. Mulroy S, Gronley J, Weiss W, et al. Use of cluster analysis for gait pattern classification of patients in the early and late recovery phases following stroke. Gait and Posture. 2003; 18: 114-25.

34. Phinyomark A, Osis S, Hettinga BA, Ferber R. Kinematic gait patterns in healthy runners: A hierarchical cluster analysis. J Biomech. 2015; 48 (14): 3897-904.

35. Watari R, Osis ST, Phinyomark A, Ferber R. Runners with patellofemoral pain demonstrate sub-groups of pelvic acceleration profiles using hierarchical cluster analysis: an exploratory crosssectional study. BMC Musculoskeletal Disorders. 2018; 19: 120.

36. Trompetto C, Marinelli L, Mori L, et al. Postactivation depression changes after robotic-assisted gait training in hemiplegic stroke patients. Gait Posture. 2013; 38 (4): 729-33.

37. Скворцов Д. В. Диагностика двигательной патологии инструментальными методами: анализ походки стабилометрия. M., 2007; 640 c.

38. Витензон А. С., Петрушанская К. А. К фазовому анализу ходьбы и некоторых ритмических движений человека. Российский журнал биомеханики. 2005; 9 (1): 7-26.

39. Воронцова О. И., Лозовская М. В. Структура шагового цикла по данным анализа кинетических и кинематических параметров походки человека. Вестник новых медицинских технологий. 2017; 3: 9-15.

40. Bonnyaud C, Zory R, Boudarham J, et al. Effect of a robotic restraint gait training versus robotic conventional gait training on gait parameters in stroke patients. Exp Brain Res. 2014; 232 (1): $31-42$. 